\title{
Effects of Fish Meal Substitution with Poultry By-product Meal on Growth Performance, Nutrients Utilization and Blood Contents of Juvenile Nile Tilapia (Oreochromis niloticus)
}

Yones AMM* and Metwalli AA

National Institute of Oceanography and Fisheries, Shakshouk Fish Research Station, El-Fayoum, Egypt

\begin{abstract}
Four isonitrogenous and isocaloric diets $\left(30.22 \pm 0.02 \% \mathrm{CP}\right.$ and $19.007 \pm 0.015 \mathrm{MJ} \mathrm{kg}^{-1}$ diet) were formulated to represent four dietary treatments. The first treatment (control) without poultry by-product (PM0), while the second, third and fourth diets formulated with substitution of fish meal by poultry by-product meal as 50,75 and $100 \%$, respectively. Each diet was fed to 100 juvenile tilapia $(1.5 \pm 0.05 \mathrm{~g})$, in triplicate cement ponds of $2 \mathrm{~m}^{3}$. Fish were fed diets at a rate of $3 \%$ of its biomass daily divided into two equal portions. The highest $(P<0.05)$ growth performance parameters (finial weight, weight gain, daily gain and specific growth rate) and best nutrient utilization (feed conversion ratio, protein efficiency ratio and net protein utilization) were recorded with $\mathrm{PBM} 0$ and $\mathrm{PBM} 100 \%$ groups. The applied treatments showed insignificant effects on nutrients digestibility coefficient among dietary groups for Dry matter, Energy, CP, Fat and nitrogen free extract. No significant effects on dry matter, crude protein, fat and ash contents were recorded between dietary treatments. Juvenile tilapia fed the experimental diets showed insignificant different in blood contents $(P<0.05)$ between groups. The present study recommended substitution of $100 \%$ fish meal with poultry by-product meal in juvenile Nile tilapia diets.
\end{abstract}

Keywords: Oreochromis niloticus; Poultry by-product meal; Digestibility coefficient; Growth performance; Blood contents

\section{Introduction}

The global production of tilapia drastically increased from 124 thousand metric tons (Mt) in 1997 to 2.5 million Mt in 2010 [1]. This trend suggests that there will be even greater increases in the future. Among the cichlid species, it is the Nile tilapia (Oreochromis niloticus) that has dominated in different culture system. The tilapia market has expanded from a subsistence level to meet the protein needs of the middle class because of the year-round supply, delicious flavour and reasonable price of that fish [2]. Golbal tilapia production was recorded 3.500 .000 metric tons in 2011,3.8000.000 metric ton in 2012,4.850.000 metric ton in 2014 and by 2015 , world production tilapia is forecast to reach 4.6-5.0 million metric ton $[3,4]$.

Traditionally, fish meal has provided a major part of protein sources in formulated feeds because of its suitable protein quality. Science the recent scarcity and uncertain consistency of supply encourage its replacement by alternative protein sources that are of high quality, but less expensive has been investigated in many fish species. The limitations on the world's food supply provide additional motivation $[5,6]$. Therefore, numerous studies have undertaken to examine the effects of replacing fish meal by another source of protein such as animal by-product or plant-based protein in diets that can be fed to tilapia $[7,8]$.

Animal by-products such as meat meal, bone meal and poultry by-product meal have considerable potential as feed ingredients in fish production system [9-12] and comparatively less expensive than fish meal [13]. These animal protein ingredients are good sources of amino acids with high protein content, total digestible dry matter and energy similar to fish meal [9]. Therefore, poultry by-product meal is considered a probable replacement for fish meal [14-21]. Many studies have also shown that animal protein ingredients can be useful for fish feed formulation and they are comparatively much less expensive than fish meal $[13,22,23]$.
Some studies have shown that poultry by-product meal cannot replace more than $50 \%$ of fish meal in fish diets [24], but other studies have shown that with the recent improvement of the quality of poultry by-product meal it could replace $75 \%$ or $100 \%$ of fish meal without significant decrease in fish growth [25-28].

The present study aims to evaluate the effects of use poultry byproduct meal as a alternative protein source to replace fish meal on growth performance, nutrient utilization, digestibility coefficient and some blood constituents of Nile tilapia (Oreochromis niloticus) reared in cement tanks.

\section{Materials and Methods}

\section{Fish culture and experimental diets}

The present study was conducted using the research facilities of the experimental station at Shakshouk, Fayoum Governorate, National Institute of Oceanography and Fisheries (NIOF). The system contained two water pumps and upstream sandy filter units at a point between the water source and tanks. Each pump was drowning the water from the lake Qaroun to collection cement pond and forced it through storage units and then to the rearing tanks in open system. Physicochemical characteristics of water tanks were examined every week, (Table 1) according to APHA [29].

*Corresponding author: Yones AMM, National Institute of Oceanography and Fisheries, Shakshouk Fish Research Station, El -Fayoum, Egypt, Tel: (+202) 7921342; E-mail: yones_552000@yahoo.com

Received September 10, 2015; Accepted October 19, 2015; Published January 15, 2016

Citation: Yones AMM, Metwalli AA (2015) Effects of Fish Meal Substitution with Poultry By-product Meal on Growth Performance, Nutrients Utilization and Blood Contents of Juvenile Nile Tilapia (Oreochromis niloticus). J Aquac Res Development 6: 389. doi:10.4172/2155-9546.1000389

Copyright: @ 2015 Yones AMM, et al. This is an open-access article distributed unde the terms of the Creative Commons Attribution License, which permits unrestricted use, distribution, and reproduction in any medium, provided the original author and source are credited. 
Citation: Yones AMM, Metwalli AA (2015) Effects of Fish Meal Substitution with Poultry By-product Meal on Growth Performance, Nutrients Utilization and Blood Contents of Juvenile Nile Tilapia (Oreochromis niloticus). J Aquac Res Development 6: 389. doi:10.4172/2155-9546.1000389

\section{Diets}

\begin{tabular}{|l|c|c|c|c|}
\hline Parameters & PBM0 & PBM50 & PBM75 & PBM100 \\
\hline Temperature ${ }^{\circ} \mathrm{C}$ & $27.0 \pm 0.12$ & $27.1 \pm 0.12$ & $27.4 \pm 0.1$ & $27.1 \pm 0.15$ \\
\hline pH & $7.6 \pm 0.1$ & $7.8 \pm 0.12$ & $7.8 \pm 0.11$ & $7.6 \pm 0.1$ \\
\hline Dissolved oxygen $\left(\mathrm{mg} \mathrm{l}^{-1}\right)$ & $6.3 \pm 0.11$ & $6.2 \pm 0.12$ & $6.2 \pm 0.11$ & $6.1 \pm 0.12$ \\
\hline Salinity $\left(\mathrm{g} \mathrm{l}^{-1}\right)$ & $2.22 \pm 0.1$ & $2.23 \pm 0.1$ & $2.22 \pm 0.1$ & $2.22 \pm 0.1$ \\
\hline Unionized ammonia $\left(\mathrm{mg} \mathrm{l}^{-1}\right)$ & $0.03 \pm 0.01$ & $0.028 \pm 0.01$ & $0.026 \pm 0.002$ & $0.028 \pm 0.001$ \\
\hline
\end{tabular}

Table 1: Averages of water physicochemical characteristics parameters during experimental period

\begin{tabular}{|c|c|c|c|c|c|c|}
\hline Ingredientes & DM & CP & EE & NFE & CF & ASH \\
\hline Fish meal & 916 & 700 & 128 & - & - & 172 \\
\hline Poultry by-product meal & 921 & 560 & 134 & 128 & 24 & 154 \\
\hline Soybean meal & 915 & 480 & 44 & 368 & 42 & 66 \\
\hline Gluten meal & 906 & 350 & 48 & 532 & 22 & 48 \\
\hline Wheat bran & 904 & 144 & 34 & 666 & 92 & 68 \\
\hline Yellow maize & 896 & 90 & 24 & 760 & 72 & 54 \\
\hline
\end{tabular}

DM: Dry Matter, CP: Crude Protein, EE: Ether Extract, NFE: Nitrogen Free Extract, CF: Crude Fiber.

Table 2: Proximate composition of feed ingredients $\left(\mathrm{g} \mathrm{kg}^{-1} \mathrm{~d} . \mathrm{m}\right) \mathrm{n}=3$.

The fry of Nile tilapia (Oreochromis niloticus) used in the present study were obtained after brood stock hatching in the station. The fry were acclimatized for two weeks in rearing tanks and fed on prepared powder diet contain $30 \%$ crude protein, formulated from the same ingredients use in the growth trial. Juvenile tilapia with an initial average weight of $1.5 \pm 0.05 \mathrm{~g}$ were randomly distributed and stocked at 100 juvenile per tank in 12 cement tanks, each with a water volume of $\left(2 \mathrm{~m}^{3}\right)$ and the treatments were performed in triplicates. The diets were given at $3 \%$ of live body weight (BW) and offered in two equal portions at 10.00 a.m and 16.00 p.m. The experiment lasted 120 days after start.

Four isonitrogenous diets were formulated to contain an average of $30.11 \pm 0.07 \%$ crude protein for meeting the recommended nutritional requirements of tilapia [30]. The ingredients were obtained from Zoocontrol fish Co at 6 October city, Egypt. Ingredients, diets formulation and chemical composition analysis are presented in Tables 2 and 3 . The first diet was formulated without poultry by-product meal and considered as a control diet (PM0), Diets 2 (PM50), 3 (PM75) and 4 (PM100) were formulated to be comprised with partial and total inclusion levels of 50, 75 and $100 \%$ poultry by-product meal, respectively. All diets were processed into dry sinking pellet form, using California pelleting machine with $1 \mathrm{~mm}$ diameter.

\section{Apparent digestibility coefficient}

The experimental test diets with addition of $0.5 \%$ chromic oxide $\left(\mathrm{Cr}_{2} \mathrm{O}_{3}\right)$ were fed to fishes after the growth trial lasted for a period of two week in order to study the apparent digestibility coefficient (ADC $\%)$ of nutrients. Any uneaten and fecal residues were siphoned out from the tank bottom after two hours of first feeding (10.00 a.m.) and discarded. Fish fecal samples were collected every afternoon before the second feeding, new fecal materials were carefully siphoned and collected using the filtration system developed by Choubert et al. [31]. After freeze-drying of $20 \mathrm{~g}$ fecal samples in each replicate tank, the feces were analyzed. Dry matter was calculated by gravimetric analysis at $105^{\circ} \mathrm{C}$ for $24 \mathrm{hrs}$. Chromic oxide levels were determined spectrometry (Spectra, AA220FSNarin) based on the method described by Bolin et al. [32].

The apparent digestibility coefficients ADC for test diets were calculated according to the equation described by Cho [33].

$$
\left.\operatorname{ADC}(\mathrm{n})=100-\left\{100\left(\% \mathrm{Cr}_{2} \mathrm{O}_{3} \mathrm{~d}\right) / \% \mathrm{Cr}_{2} \mathrm{O}_{3} \mathrm{f}\right) \times(\% \mathrm{Nf} / \% \mathrm{Nd})\right\} \text {. }
$$

Where $\mathrm{ADC}(\mathrm{n})=$ apparent digestibility coefficients of a nutrient in the test diets; $\mathrm{Cr}_{2} \mathrm{O}_{3} \mathrm{~d}=\%$ chromic oxide of the diet; $\mathrm{Cr}_{2} \mathrm{O}_{3} \mathrm{f}=\%$ chromic oxide of the feces; $\mathrm{Nd}=$ nutrient in the test diet; $\mathrm{Nf}=$ nutrients in feces.

\section{Chemical analysis}

The chemical composition of the experimental diets, feces and whole fish samples was performed via proximate composition analysis according to standard methods [34]. Briefly dry matter was determined gravimetrically in an oven dried samples at $105^{\circ} \mathrm{C}$ for $24 \mathrm{~h}$, protein $(\mathrm{N} \times 6.25)$ content was determined using Kjeldhal method and crude fat by chloroform-methanol extraction (2:1) using Soxhlet system. Ash was determined by incinerating samples in a Germany muffle furnace at $550^{\circ} \mathrm{C}$ for $18 \mathrm{~h}$. Nitrogen free extract (NFE) was calculated by the difference.

Diets samples were hydrolyzed in $6 \mathrm{~N}(\mathrm{HCL})$ at $106^{\circ} \mathrm{C}$ over $24 \mathrm{~h}$ in nitrogen-flushed glass vials before amino acid analysis. Total amino acids were analysed by high pressure liquid chromatography (HPLC) in a Pico-Tag amino acid analysis system (Water, Bedford, MA, (USA), using norleucine as internal standard and according to the procedure described by Cohen et al. [35].

Gross energy ( $\mathrm{MJ} \mathrm{Kg}^{-1}$ diet) was calculated according to Schulz et al. [36] using the following calorific values: $23.9,39.8$ and $17.6 \mathrm{MJ} \mathrm{g}^{-1}$ diet for protein, ether extract and nitrogen free extract, respectively. The metabolizable energy contents of the experimental diets were calculated as 18.9, 35.7 and $14.7 \mathrm{MJ} \mathrm{g}^{-1}$ diet for protein, lipid and nitrogen free extract, respectively according to Jobling [37].

\begin{tabular}{|c|c|c|c|c|}
\hline \multicolumn{4}{|l|}{ Diets } & \multirow[b]{2}{*}{ PBM100 } \\
\hline Ingredients & PBMO & PBM50 & PBM75 & \\
\hline Fish meal & 200 & 100 & 50 & - \\
\hline Poultry by-product meal & - & 150 & 200 & 260 \\
\hline Soybean meal & 150 & 130 & 150 & 150 \\
\hline Corn gluten meal & 110 & 100 & 100 & 100 \\
\hline Wheat brain & 200 & 200 & 200 & 2100 \\
\hline Yellow corn maize & 260 & 240 & 220 & 200 \\
\hline Fish oil & 30 & 30 & 30 & 30 \\
\hline Sunflower oil & 30 & 30 & 30 & 30 \\
\hline Vitamin and mineral mix ${ }^{1}$ & 15 & 15 & 15 & 15 \\
\hline Chromic oxide & 5 & 5 & 5 & 5 \\
\hline \multicolumn{5}{|l|}{ Proximate analysis $(n=3)$} \\
\hline Dry matter & 928 & 922 & 924 & 926 \\
\hline Crude protein & 301.9 & 301 & 301.8 & 300 \\
\hline Ether extract & 110.4 & 115.9 & 116.6 & 118.8 \\
\hline Nitrogen free extract & 453.9 & 451.3 & 449.2 & 447.8 \\
\hline Crude fiber & 45.8 & 46.8 & 50.4 & 49.4 \\
\hline Crude ash & 88 & 85 & 82 & 84 \\
\hline Gross energy (MJ kg-1 diet) ${ }^{2}$ & 19.58 & 19.74 & 19.75 & 19.77 \\
\hline $\mathrm{ME}\left(\mathrm{MJ} \mathrm{kg}^{-1} \mathrm{diet}\right)^{3}$ & 16.31 & 16.44 & 16.46 & 16.49 \\
\hline
\end{tabular}

${ }^{1}$ Vitamin-mineral premix, $\mathrm{mg} \mathrm{Kg}^{-1}$ dry diets: vitamin A (as acetate), $7500 \mathrm{lu} \mathrm{kg}^{-1} \mathrm{dry}$ diet, Vitamin D3 (as cholecalcipherol); $6000 \mathrm{IU} \mathrm{kg}^{-1}$ dry diet, vitamine E (as DL-Ltocopheryl-acetate); $150 \mathrm{IU} \mathrm{kg}^{-1}$ dry diet, vitamin k (as menadione Na-bisulphate) 0.06 ascorbic acid (as ascorbyle polyphosphate), $150 \mathrm{D}$-biotin, 42 choline (as chloride) 3000; folic acid, 3 niacin (as nicotinic acid), 30 pantothenic acid, 60 pyridoxine, 15; ribflavine, 0.06; manganese sulphate, 0.18 ; potassium iodide, 0.02 zinc sulphate.

${ }^{2}$ Schulz et al. [36].

3Jobling [37].

Table 3: Formulation and approximate composition of experimental diets $\left(\mathrm{g} \mathrm{kg}^{-1}\right)$. 
Citation: Yones AMM, Metwalli AA (2015) Effects of Fish Meal Substitution with Poultry By-product Meal on Growth Performance, Nutrients Utilization and Blood Contents of Juvenile Nile Tilapia (Oreochromis niloticus). J Aquac Res Development 6: 389. doi:10.4172/2155-9546.1000389

Page 3 of 6

\section{Growth performance and feed utilization}

Standard formulae were used to assess growth-feed utilization and other relevant parameters during the growth trial and these included, initial average weight, final average weight, total feed consumed, weight gain $(\mathrm{g})$, average daily gain ( $\mathrm{g}$ fish day $\left.{ }^{-1}\right)$, specific growth rate (SGR\% day $^{-1}$ ), feed conversion ratio (FCR), protein efficiency ratio (PER) and net protein utilization (NPU\%).

\section{Blood assays}

Blood samples were collected using heparinized syringes from the caudal vein of the experimental fish at the end of the growth trial. Blood samples were centrifuged at $3000 \mathrm{rpm} \times 15 \mathrm{~min}$ at $4^{\circ} \mathrm{C}$ to allow separation of plasma which use to determine the blood parameters. Total plasma protein were carried out using Colorimeteric method, (Roch Diagnostics, GmbH, Monnheim, Germany) as recorded by Ruane et al. [38]. Creatinine was determined according to Pincus [39]. The activities of aspartate aminotransferase (AST) and alanine aminotransferase (ALT) were carried out using Colorimeteric method, Roch Diagnostics, GmbH, Monnheim, Germany kits according to Reitman and Frankel [40].

\section{Statistical analysis}

One way Analysis of Variance (ANOVA) was applied to test the effects of partially and totally replacement of poultry-by product meal on various growth parameters, chemical composition, blood constituents and apparent digestibility coefficients according to Snedecore and Cochran [41]. Duncan Multiple Range test was used to detect the significant differences between the means of treatments [42]. All analysis were performed using SAS (version 9.1 2004 SAS Institute, Cary, NC, USA) [43]. The level of significance was chosen at $p \leq 0.05$ and the results are presented as a group means $(n=3$ per tanks in each treatments \pm S.E.M.).

\section{Results}

\section{Physicochemical characteristics}

Water physicochemical characteristics (Table 1) revealed that temperature, $\mathrm{pH}$, dissolved oxygen, salinity and unionized ammonia are within the optimum ranges for rearing Nile tilapia according to Wangead et al., El-Shafai et al. and Ferreira et al. [44-46]. Similar physicochemical conditions were found in all tanks.

\section{Chemical composition of diets}

As can be seen in Table 3, the four experimental diets were almost similar in protein content (30.0-30.19\%) and gross energy (19.58-19.77 $\mathrm{MJ} \mathrm{kg}{ }^{-1}$ diets). However, they differed in their amino acids contents (Table 4). The all essential amino acids met the requirements of this species as recommended by NRC.

\section{Growth performance}

As presented in Table 5 averages of initial weights ranged between 1.5 to $1.6 \mathrm{~g} /$ fish with insignificant differences among the dietary groups indicating the random distribution of the experimental fish among treatment groups. Concerning finial weights the fish fed the tested treatments recorded an insignificant values $(\mathrm{P}<0.05)$ between each other. The same trend was observed with total gain in weight, the daily gain and specific growth rate of fish fed the different inclusion levels (50, 75 and $100 \% \mathrm{PM})$ of poultry by-product meal.

As shown in Table 5 average amounts of feed intake were found

\begin{tabular}{|l|c|c|c|c|c|}
\hline Diets & \multicolumn{5}{|l}{} \\
\hline Amino acids & RE $^{*}$ & PBM0 & PBM50 & PBM75 & PBM100 \\
\hline Essential amino acids & & & & & \\
\hline Arginine & 11.8 & 16.8 & 17.4 & 18.2 & 18.3 \\
\hline Hisitdine & 8.4 & 9.2 & 8.8 & 8.9 & 9.1 \\
\hline Lysine & 14.3 & 14.6 & 14.8 & 14.5 & 14.8 \\
\hline Leucine & 9.5 & 20.4 & 21.6 & 22 & 22.4 \\
\hline Isoleucine & 8.7 & 10.8 & 11.3 & 11.7 & 12 \\
\hline Valine & 7.8 & 13.8 & 14.8 & 15.3 & 15.8 \\
\hline Methionine +Cystine & 9 & 9.8 & 9.6 & 10.4 & 12.1 \\
\hline Threonine & 10.5 & 10.3 & 11.1 & 11.6 & 11.9 \\
\hline Phenyl alinine+Tyrosine & 15.5 & 20.7 & 20.4 & 24.9 & 24.5 \\
\hline Tryptophan & 2.8 & 2.9 & 3.1 & 3 & 3.1 \\
\hline Non essential amino acids & & & & & \\
\hline Glutamic acid & - & 43 & 42.9 & 43.8 & 43.9 \\
\hline Aspartic acid & - & 24.3 & 24.2 & 24.9 & 24.5 \\
\hline Glycine & - & 18.8 & 19.2 & 18.9 & 17.9 \\
\hline Serine & - & 11.7 & 15 & 16.4 & 17.7 \\
\hline Proline & - & 18.4 & 20.4 & 21.1 & 21.8 \\
\hline
\end{tabular}

${ }^{*}$ Requirements according to, NRC (2011).

Table 4: Amino acids contents of the experimental diets $\left(\mathrm{g} \mathrm{kg}^{-1}\right) \mathrm{n}=3$.

\section{Diets}

\begin{tabular}{|c|c|c|c|c|}
\hline Parameters & PBMO & PBM50 & PBM75 & PBM100 \\
\hline Initial average weight ( $\mathrm{g} \mathrm{fish}^{-1}$ ) & $1.5 \pm 0.05$ & $1.6 \pm 0.06$ & $1.6 \pm 0.05$ & $1.5 \pm 0.06$ \\
\hline Final average weight $\left(\mathrm{g} \mathrm{fish}^{-1}\right)$ & $54.6 \pm 2.5$ & $53.8 \pm 1.8$ & $54.1 \pm 2.0$ & $54.3 \pm 1.5$ \\
\hline Gain in weight $\left(\mathrm{g} \mathrm{fish}^{-1}\right)$ & $53.1^{\mathrm{a}} \pm 1.1$ & $52.2^{\mathrm{a}} \pm 1.4$ & $52.5^{\mathrm{a}} \pm 1.5$ & $52.8^{\mathrm{a}} \pm 1.6$ \\
\hline Average daily gain (g fish day ${ }^{-1}$ ) & $0.44 \pm 0.15$ & $0.43 \pm 0.2$ & $0.43 \pm 0.3$ & $0.44 \pm 0.1$ \\
\hline Specific growth rate $\left(\% \text { day }^{-1}\right)^{1}$ & $3.0 \pm 0.5$ & $2.92 \pm 0.4$ & $2.93 \pm 0.2$ & $2.99 \pm 0.3$ \\
\hline Feed consumed $\left(\mathrm{g} \mathrm{fish}^{-1}\right)$ & $70.0 \pm 3.0$ & $71.0 \pm 2.0$ & $71.0 \pm 4.0$ & $71.0 \pm 3.0$ \\
\hline Feed conversion ratio ${ }^{2}$ & $1.31 \pm 0.15$ & $1.36 \pm 0.2$ & $1.35 \pm 0.2$ & $1.34 \pm 0.1$ \\
\hline Protein efficiency ratio ${ }^{3}$ & $2.51 \pm 0.2$ & $2.44 \pm 0.15$ & $2.45 \pm 0.18$ & $2.46 \pm 0.16$ \\
\hline Net Protein Utilization (NPU\%) ${ }^{4}$ & $39.75 \pm 4.0$ & $37.10 \pm 3.0$ & $37.98 \pm 3.0$ & $38.51 \pm 4.0$ \\
\hline
\end{tabular}

Values are the mean \pm S.E. of triplicate groups of each treatment.

'Specific growth rate $=100 \times($ Ln final weight- Ln initial weight $) / 120$ day.

${ }^{2}$ Feed conversion $=($ feed given per fish $) /$ (weight gain per fish) .

${ }^{3}$ Protein efficiency ratio $=$ (weight gain per fish $) /$ (protein intake per fish).

${ }^{4} \mathrm{Net}$ protein utilization $(\%)=($ final body protein - initial body protein $) /($ protein intake $)$ $\times 100$.

Table 5: Growth performance of Nile tilapia fed the experimental diets.

to be 70.0, 71.0, 71.0 and 71.0 g for the PBMO, PBM50, PBM75 and PBM100\% groups, respectively. On the other hand, the best FCR (lowest) values were obtained by the PBMO group without significant differences $(\mathrm{P}<0.05)$ were registered among treatments. As presented in the same table the PER and NPU values showed an insignificant values between the different groups.

\section{Apparent digestibility coefficient}

Data on apparent digestibility coefficients in present study for dry matter $(\mathrm{DM})$, energy $(\mathrm{E})$, crude protein $(\mathrm{CP})$, fat and nitrogen free extract (NFE) are presented in Table 6. Results revealed that apparent digestibility coefficients DM, E, CP, fat and NFE were not significantly affected with the inclusion levels of poultry by-product meal.

\section{Blood characteristics}

Blood characteristics revealed that insignificant differences 


\section{Diets}

\begin{tabular}{|l|c|c|c|c|}
\hline Nutrients & PBM0 & PBM50 & PBM75 & PBM100 \\
\hline Dry matter & $85.8 \pm 3.0$ & $85.5 \pm 2.0$ & $85.6 \pm 1.0$ & $85.4 \pm 2.0$ \\
\hline Energy & $90.4 \pm 4.0$ & $89.8 \pm 2.0$ & $89.6 \pm 3.0$ & $90.2 \pm 1.0$ \\
\hline Protein & $94.4 \pm 3.0$ & $94.5 \pm 4.0$ & $94.3 \pm 2.0$ & $94.6 \pm 3.0$ \\
\hline Fat & $95.5 \pm 2.0$ & $95.3 \pm 2.0$ & $95.4 \pm 3.0$ & $95.6 \pm 3.0$ \\
\hline Nitrogen free extract & $71.8 \pm 1.0$ & $71.9 \pm 3.0$ & $71.6 \pm 2.0$ & $71.5 \pm 4.0$ \\
\hline
\end{tabular}

Table 6: Apparent digestibility coefficients (\%) for the experimental diets (Mean \pm S.E $n=3)$.

\begin{tabular}{|l|c|c|c|c|}
\hline Diets \\
\hline Parameters & PBM0 & PBM50 & PBM75 & PBM100 \\
\hline Total protein g/dl & $6.4 \pm 1.11$ & $6.4 \pm 0.8$ & $6.42 \pm 0.9$ & $6.3 \pm 0.6$ \\
\hline Albumin g/dl & $3.22 \pm 0.33$ & $3.24 \pm 0.22$ & $3.3 \pm 0.32$ & $3.26 \pm 0.2$ \\
\hline Urea mg/dl & $7.2 \pm 0.14$ & $7.13 \pm 0.12$ & $7.3 \pm 0.16$ & $7.5 \pm 0.15$ \\
\hline Creatinine & $1.12 \pm 0.3$ & $1.14 \pm 0.34$ & $1.16 \pm 0.2$ & $1.18 \pm 0.26$ \\
\hline Ast $^{1}$ & $116.0 \pm 0.65$ & $117.0 \pm 0.48$ & $124.0 \pm 0.56$ & $126.0 \pm 0.52$ \\
\hline Alt $^{2}$ & $44.0 \pm 0.41$ & $44.0 \pm 0.32$ & $45.0 \pm 0.22$ & $44.5 \pm 0.38$ \\
\hline
\end{tabular}

Values are the mean \pm S.E. of triplicate groups of 20 fishes

1-Aspartate aminotransferase 2-Alanine aminotransferase

Table 7: An average of blood characteristics parameters of tilapia fed the experimental diets.

\begin{tabular}{|l|c|c|c|c|c|}
\hline Diets \\
\hline Items & Initial & PBM0 & PBM50 & PBM75 & PBM100 \\
\hline Dry matter & $242 \pm 1.6$ & $271 \pm 3.18$ & $270 \pm 3.6$ & $276 \pm 3.14$ & $274 \pm 1.16$ \\
\hline Crude protein & $152 \pm 1.8$ & $158 \pm 2.16$ & $152 \pm 2.2$ & $156 \pm 2.2$ & $154 \pm 2.11$ \\
\hline Crude lipid & $32 \pm 1.5$ & $55 \pm 1.8$ & $62 \pm 1.6$ & $61 \pm 1.4$ & $58 \pm 1.16$ \\
\hline Crude ash & $58 \pm 1.2$ & $58 \pm 1.4$ & $56 \pm 1.6$ & $59 \pm 1.2$ & $54 \pm 1.6$ \\
\hline
\end{tabular}

Table 8: Carcass analysis of Nile tilapia fed the experimental diets $\left(\mathrm{g} \mathrm{kg}^{-1}\right.$ wet basis) mean \pm S.E. $n=3$.

$(\mathrm{P}<0.05)$ were detected between the experimental groups (Table 7$)$ for total protein, albumin, creatinine, Aspartate aminotransferase (Ast) and Alanine aminotransferase (Alt) of tilapia, which indicate that substitution of fish meal by poultry by-product had no hazardous effects on blood parameters tested.

\section{Carcass analysis}

Results of whole fish body composition in terms of wet weight, were not significantly affected $(\mathrm{P}<0.05)$ by the increment of PBM levels. The chemical analysis showed that the applied dietary treatments had no significant effects $(\mathrm{P}<0.05)$ on whole body dry mater, crude protein, fat and ash content between groups (Table 8 ).

\section{Discussion}

The replacement of dietary FM in aqua feeds with readily available and more economical alternatives sources, such as poultry byproduct meal is an important aim for each aquaculture industry and feed-manufacture company. This by-product of poultry processing industry is high in protein, low price and contains a favorable profile of indispensable amino acids for fish production.

The results of the present study indicated that PBM is a suitable replacement of fish meal in practical formulation diets for juvenile tilapia.

The growth performance (final weight gain, daily gain and specific growth rate) and nutrient utilization (feed conversion ratio, protein efficiency ratio and net protein utilization) of tilapia has shown enhancement for dietary PBM without significant reduction when the replacement level of fish meal up to $100 \%$. These findings are in agreement with other studies in tilapia [47]. However, PBM can be used to replace $75 \%$ of the fish meal in diets without amino acid supplementation for gilthead sea bream [26] up to $100 \%$, red sea bream [27], sunshine bass [48]; grouper [49] and gible carp [50]. In contrast, fish meal could only be replaced with PBM at a level which did not exceed $50 \%$ for some marine fish species [51-53]. In the present study the growth performance and feed utilization recorded comparable results with fish meal diets. In contrast, Rawles et al. [16], recorded that PBM had lower growth than fish fed the control diet with FM in sunshine bass. They attributed that imbalance of some limiting amino acid content may have caused reduced growth performance in sunshine bass. They also speculated that reduced growth observed in this species may be due to reduced palatability for PBM. However, in the current study the balance in limiting amino acid, all diets were consumed similarly and different species may be enhance the growth performance in juvenile tilapia.

As can be seen from Table 5, the FCR, PER and NPU were not significantly differed $(\mathrm{P}<0.05)$ between groups and the best value was recorded by PBM0. Similar and comparable results of FCR, PER and NPU were recorded with tilapia $[47,54,55]$.

Amongst the experimental diets in the present trial, fish receiving the PM0 and PM100 diets showed high growth performance and net protein utilization. This result is in agreement with the other several warm water finfish species obtained by Hernandez et al. and Pine et al. $[47,56]$. They recorded that poultry by-product has been shown to enhanced growth performance of Nile tilapia and sunshine bass.

The major reasons for different results may be due to the different fish species and the varying quality of tested PBM, which are significantly influenced by their processing methods [49].

The experimental diets in the present study showed a good digestibility coefficient for the tested diets. These results are in agreement with the results of Hernandez et al. [47]. Similar and comparable ADC values of feed dry matter, protein, lipid and energy were also observed by several authors in digestibility studies with tilapia fed the conventional commercial ingredient [55,57-60]. Similar results were recorded in rainbow trout by Burea et al. $[9,23]$.

The carcass proximate composition of tilapia indicated that the dry matter, protein, lipid and ash were not affected by incorporation of $100 \%$ poultry by-product meal. Similar results have been reported for tilapia by Hernandez et al. [47] and sunshine bass [56], grouper [53] and gibel carp [50].

Measures of blood parameters not significantly different between treatments, where the total protein, albumin, urea, creatinine Ast and Alt are comparable with the control diet. These results are in agreement with the previous study in tilapia recorded by Metwalli, Yue et al. $[61,62]$ and other species such as sturgeon [63] and sunshine bass [48].

Results of the present study suggest that potential replacing $100 \%$ of fish meal with poultry by-product meal in the feed of tilapia Oreochromis niloticcus, without compromising growth performance, nutrients utilization and some blood contents. It is important to establish that alternative dietary sources to fish meal are not only supplied in the correct quantities and balance for optimal growth and feed efficiency, but can maintain optimal whole body composition and blood contents. 
Citation: Yones AMM, Metwalli AA (2015) Effects of Fish Meal Substitution with Poultry By-product Meal on Growth Performance, Nutrients Utilization and Blood Contents of Juvenile Nile Tilapia (Oreochromis niloticus). J Aquac Res Development 6: 389. doi:10.4172/2155-9546.1000389

Page 5 of 6

\section{References}

1. FAO (2010) FAO Fisheries Department Fishery Information Data and Statistics Units DISHSTAT Plus: Universal software for fishery statistical time series, Version, 232000 Data sets: Aquaculture production: quantities and values 1950-2009, capture production 1950-2009.

2. Vechklang K, Boonanuntanasarn S, Ponchunchoovong S, Pirarat N, Wanapu C (2011) The potential for rice wine residual as alternative protein source in a practical diet for Nile tilapia (Oreochromis niloticus) at the juvenile stage Aquaculture Nutrition 17: 685-694.

3. Burden D (2012) Tilapia profile International and special projects lowa State university.

4. Fitzsimmons (2014) World tilapia production 4 international trade and technical conference and exposition on tilapia, Kuala Lumpur Malaysia.

5. Naylor RL, Goldburg RB, Primavera JH, Kautsky N, Beveridge MCM, et al (2000) Effect of aquaculture on world fish supplies Nature 405: 1017-1024

6. New MB, Wijkstrom UN (2002) Use of fish meal and fish oil in aqua feed: further thoughts on the fish meal trap FAO fish circular No 975, FAO, Rome Italy.

7. Cavalheiro JMO, Souza EO, Bora PS (2007) Utilization of shrimp industry waste in the formulation of tilapia (Oreochroms niloticus Linnaeus) feed. Bioresour Technol 98: 602-606.

8. Nguyen TN, Davis DA (2009) Evaluation of alternative protein sources to replace fish meal in practical diets for Juvenile Tilapia, Oreochromis spp. J World Aquaculture Soc 40: 113-121.

9. Bureau DP, Harris AM, Bevan DJ, Simmons LA, Azevedo PA, et al. (2000) Feather meals and meat bone meals from different origins as protein sources in rainbow trout (Oncorhynchus mykiss) diets. Aquaculture 181: 281-291.

10. Millamena OM (2002) Replacement of fish meal by animal by-product meals in a practical diets for grow-out culture of grouper (Epinephelus coioides). Aquaculture 204: 75-84.

11. Wei Z, Kangsen M, Baigang Z, Fuzhen W, Yu U (2004) A study on the meat and bone meal and poultry by-product meal as protein substitutes of fish meal in practical diets for (Lipopenaeus vannami) juveniles. J Ocean Univ China (Ocean, Coast Sea Res) 3: 157-160.

12. Fasakin EA, Serwata RD, Davies SJ (2005) Comparative utilization of rendered animal derived products with or without composite mixture of soybean meal in hybrid tilapia (Oreochromis niloticcus $\times$ mossambicus) diets. Aquaculture 249 : 324-338.

13. Abdel-Warith A, Davies SJ, Russell P (2001) Inclusion of commercial poultry by-product meal as a protein replacement of fish meal in practical diets for the African cat fish (Claris gariepinus). Aquacult Res 32: 296-306.

14. Gaylord TG, Rawles SD (2005) The modification of poultry by-product meal for use in hybrid striped bass (Morone chrysops $\times$ Msaxatilis) diets. J World Aquac Soc 36: 363-374.

15. Muzinic LA, Thompson KR, Metts LS, Dascupta S, Webster CW (2006) Use of turkey meal as partial and total replacement of fish meal in practical diets for sunshine bass (Morone chrysops $\times$ Morone saxatilis) grown in tanks Aquaculture 12: 71-81.

16. Rawles SD, Richie M, Gaylord TG, Webb J, Freeman DW, et al. (2006) Evaluation of poultry by-product meal in commercial diets for hybrid striped bass (Morine chrysops $\times$ Morone saxatilis) in recirculated tank production Aquaculture 259: 377-389.

17. Thompson KR, Metts LS, Muzinic LA, Dascupta S, Webster CD, et al. (2007) Use of turkey meal as a replacement for menhaden fish meal in practical diets for sunshine bass grown in cages N Am J Aquacult 69: 351-359.

18. Soltan MA (2009) Effect of dietary fish meal replacement by poultry by-product meal with different grain source and Enzyme supplementation on performance, feces recovery, body composition and nutrient balance of Nile tilapia. Pakistan Journal of Nutrition 8: 395-407.

19. El-Sayed AF (1998) Total replacement of fish meal with animal protein sources in Nile tilapia (Oreochromis niloticus L) feeds. Aquaculture 29: 275-280.

20. Yang Y, Xie SQ, Cui YB, Zhu XM, Lei W, et al. (2006) Partial and total replacement of fish meal with poultry by-product meal in diets for gibel carp, Carassius auratus gibelio Bloch. Aquaculture Research 37: 40-48.

21. Soaud IP, Rodgers LJ, Davis DA, Rouse DB (2008) Replacement of fish meal with poultry by-product meal in practical diets for red claw crayfish (Cherax quadrinatus). AquacultNutr 14: 139-142.

22. Rodriguez-Serna M, Olvera-Novoa MA, Carmona-Osalda C (1996) Nutritional value of animal by-product meal in practical diets for Nile tilapia (Oreochromis niloticus L) fry. AquacultRes 27: 67-73.

23. Bureau DP, Harris AM, Cho CY (1999) Apparent digestibility of rendered animal protein ingredients for rainbow trout (Oncorhynchus mykiss). Aquaculture 180 345-358.

24. Fowler LG (1991) Poultry by-product meal as a dietary protein source in fall chinook salmon diets. Aquaculture 99: 309-321.

25. Alexis MN, Paparaskeva-Papoutsoglou E, Theochri V (1985) Formulation of practical diets for rainbow trout (Salmo gairdneri) made by partial or complete substitutes for fish meal by poultry by-product and certain plant by-products. Aquaculture 50: 61-73.

26. Nengas L, Alexis MN, Davies SJ (1999) High inclusion levels of poultry meal and related byproducts in diets for gilthead sea bream (Sparus aurata L). Aquaculture 179: 13-23.

27. Takag S, Hosokawa H, Shimeno S, Kawa MU (2000) Utilization of poultry by-product meal in a diet for red sea bream Pagrus major. Nippon Suisan Gakkaishi 66: 428-438.

28. Thompson KR, Rawles SD, Metts LS, Gannam AL, Brady YJ, et al. (2008) Digestibility of dry matter, protein, lipid and organic matter of two fish meals, two poultry by-product meals, soybean meal and distillers dried grains with solubles in practical diets for sunshine bass (Morone chrysops $\times M$ saxatilis). $J$ World Aquac Soc 309: 352-363.

29. APHA (1992) Standard methods for the examination of water and waste wate American Public Health Association, Washington, DC.

30. Jobling M (2011) National Research Council(NRC): Nutrient Requirements of fish and shrimp National Academy Press, Washington, DC, USA 20: 601-602.

31. Choubert G, De la Noue J, Luquet $P$ (1982) Digestibility in fish: improved device for the automatic collection of faeces. Aquaculture 29: 185-189.

32. Bolin DW, King RP, Klosterman EW (1952) A simplified method for the determination of chromic oxide $\left(\mathrm{Cr}_{2} \mathrm{O}_{3}\right)$ when used as an index substance. Science 116: 634-635.

33. Cho CY (1993) Digestibility of feedstuffs as a major factor in aquaculture waste management. Fish nutrition in practice. INRA, France.

34. AOAC (2006) Official methods of analysis of AOAC International (18 EDN) AOAC International Maryland, USA.

35. Cohen SA, Mamd M, Tavin TL (1989) The pico-Tag Method-A method of advanced techniques for amino acid analysis Bedford, MA, USA.

36. Schulz C, Wickert M, Kijora C, Ogunji J, Rennert B (2007) Evaluation of pea protein isolate as alternative protein source in diets for juvenile tilapia (Oreochromis niloticus). Aquaculture Research 38: 537-545.

37. Jobling M (1994) Fish bioenergetics, Fish and fisheries Series, Chapman \& Hall-2-6 Boundary, London.

38. Ruane NM, Huisman EA, Comen J (2001) Plasma cortisol and metabolite level profiles in two isogenic strains of common carp. J Fish Biol 59: 1-12.

39. Pincus MR (1996) Interpreting laboratory results reference values and decision making, Clinical Diagnosis and Management by laboratory Methods Saunders, Philadelphia, USA

40. Reitman A, Franks S (1957) Determination of aspartate glutamic amino transferase and alanin aminotransferase. American Journal of Clinical Pathology.

11. Snedecore, Gand W, Cochran WC (1987) Statistical Methods lowa state Univ USA.

42. Duncan DB (1955) Multiple ranges and multiple $F$ tests. Biometric 11: 1-42.

43. SAS (1986) SAS User's Guide Version 6 Edition SAS Institute, Cary, NCUSA

44. Wangead C, Greater A, Tansakul R (1988) Effects of acid water on survival and growth rate of Nile tilapia (Oreochromis niloticus) In: RSV Pulin, T Bhukaswan, $\mathrm{K}$ Tonguthai and $\mathrm{J}$ Maclean, Proceedings of the Second International Symposium on Tilapia in Aquaculture ICLARM Conference Proceedings No15 Deparment of Fisheries, Bangkok, Thailand ICLARM, Manila, Philippines. 
Citation: Yones AMM, Metwalli AA (2015) Effects of Fish Meal Substitution with Poultry By-product Meal on Growth Performance, Nutrients Utilization and Blood Contents of Juvenile Nile Tilapia (Oreochromis niloticus). J Aquac Res Development 6: 389. doi:10.4172/2155-9546.1000389

Page 6 of 6

45. El-Shafai SA, El-Gohary FA, Nasr FA, Der Steen NP, Gijzen HJ (2004) Chronic ammonia toxicity to duckweed-fed tilapia (Oreochromis niloticcus). Aquaculture 232: $117-127$

46. Ferreira MW, Araujo FG, Costa DV, Rosa PV, Figueiredo HCP, et al. (2011) Influence of dietary oil sources on muscle composition and plasma lipoprotein concentration in Nile tilapia (Oreochromis niloticus). Journal of World Aquaculture Society 42: 24-33.

47. Hernandez C, Olvera-Novoa AM, Hardy RW, Hemosillo A, Reyes C, et al. (2010) Complete replacement of fish meal by poultry by-product meals in practical diets for fingerlings Nile tilapia(Oreochroms niloticus) digestibility and growth performance. Aquaculture Nutrition 16: 44-53.

48. Rawles SD, Thompson KR, Brady YJ, Metts LS Aksoy MY, et al. (2011) Effects of replacing fish meal with poultry by-product meal and soybean meal and reduced protein level on the performance and immune status of pondgrown sunshine bass (Morine chrysops $\times$ Morone saxatilis). Aquacult Nutr 17: e708-e721.

49. Shapawi R, Ng WK, Mostafa S (2007) Replacement of fish meal with poultry by-product meal in diets formulated for the humpback grouper (Cromileptes altivelis). Aquaculture 273: 118-389.

50. Hu M, Wang Y, Wang Q, Zhao M, Xiong B, et al. (2008) Replacement of fish meal by rendered animal protein ingredients with lysine and methionine supplementation to practical diets for gibel carp (Carassius auratus gibelio). Aquaculture 275: 260-265.

51. El-Sayed AF (1994) Evaluation of soybean meal, spirulina meal and chicken offal meal as protein sources for silver sea bream (Rhabdosargus sarba) fingerlings. Aquaculture127: 169-175.

52. Rawles SD, Gaylord TG, McEntire ME, Freeman DW (2009) Evaluation of poultry by- product meal in commercial diets for hybrid striped bass (Morine chrysops $\times$ Morone saxatilis) in pond production. J World Aquac Soc 40: 141156.

53. Wang Y, Li K, Han H, Zheng Z, Bureu DP (2008) Potential using a blend of rendered animal protein ingredients to replace fish meal in practical diets for Malabar grouper (Epinephelus malabricus). Aquaculture 281: 133-117.

54. Gao W, Liu YGJ, Tian LX, Mai KS, Liang GY, et al. (2011) Protein sparing capability of dietary lipid in herbivorous and omnivoraus freshwater finfish a comparative case study on grass carp (Ctenopharyngodon idella) and tilapia(Oreochromis niloticus $\times$ Oaureus). Aquaculture Nutrition 17: 2-12.

55. Yones A, Abdel-Hakim NF (2010) Study on growth performance and apparent digestibility coefficients on some common plant protein ingredients used in formulated diets of Nile tilapia (Oreochromis niloticus). Egyptian Journal Nutrition and Feeds 13: 589-606.

56. Pine HJ, Daniels WH, Davis DA, Jiang M, Webster CD (2008) Replacement of fish meal with poultry by-product meal as a protein source in pond-raised sunshine bass (Morine chrysops $\times$ Morone saxatilis). Journal World Aquaculture Society 39: 586-597.

57. Shiau SY, Chuang JL, Sun CL (1987) Inclusion of soybean meal in tilapia (Oreochromis niloticus $\times$ Oreochromis aureus) diets at two protein levels. Aquaculture 65: 251-261.

58. Koprucu K, Ozdemir Y (2005) Apparent digestibility of selected feed ingredients for Nile tilapia (Oreochromus niloticus). Aquaculture Research 250: 308-316.

59. Gaye-Sliessegger J, Focken U, Abel HJ, Becker K (2005) Improving estimates of tropic shift in Nile tilapia (Oreochromus niloticus L) Comp Biochem Physiol A Mol Integr Physiol 140: 117-124.

60. Yones AM (2010) Effect of lupin kernel meal as plant protein sources in diets of red hybrid tilapia (Oreochromis niloticus $\times 0$ mossambicus), on growth performance and nutrients utilization. African Journal Biological Science 6: $1-16$.

61. Metwalli AA (2013) Effects of partial and total substitution of fish meal with corn gluten meal on growth performance, nutrients utilization and some blood constituents of the Nile tilapia (Oreochromus niloticus). Egypt J Aquat Biol \& fish17: 91-100.

62. Yue YR, Zhou QC (2008) Effect of replacing soybean meal with cottonseed meal on growth, feed utilization and hematological indexes for juvenile hybrid tilapia (Oreochromis niloticus $\times$ Oaureus). Aquaculture 284: 185-189

63. Zhu H, Gong G, Wang J, Wu X, Xue H, et al. (2011) Replacement of fish meal with blend of rendered animal protein in diets for Siberian sturgeon (Acipenser baerii), results in performance equal to fish meal fed fish. Aquacult Nutr 17 e389-e395. 